\title{
Quantitative trace element mapping in liver tissue from patients with Wilson`s disease determined by micro X- Ray fluorescence
}

\author{
W. Osterode ${ }^{1}$, G. Falkenberg ${ }^{2}$, P.Ferenci ${ }^{3}$ and F. Wrba ${ }^{4}$ \\ ${ }^{1}$ Medizinische Universität Wien, Univ. Klinik für Innere Medizin II, Institut für \\ Arbeitsmedizin \\ ${ }^{2}$ Hamburger Synchrotronstrahlungslabor HASYLAB, Deutsches Elektronen- \\ Synchrotron DESY \\ ${ }^{3}$ Medizinische Universität Wien, Univ. Klinik für Innere Medizin III, Klinisches \\ Abteilung für Gastroenterologie und Hepatologie \\ ${ }^{4}$ Medizinische Universität Wien, Klinisches Institut für Klinische Pathologie
}

${ }^{1}$ Corresponding author:

W. Osterode, MD,PhD

Medizinische Universität Wien, Univ. Klinik für Innere Medizin II

Währinger Gürtel 18-20,

A - 1090 Wien

e-mail : wolf.osterode@kabelplus.at

Keywords: Wilson's disease, trace element mapping, synchrotron X-Ray fluorescence, atomic absorption, copper, zinc, iron, sulphur, phosphorus

Abbreviations: WD, Wilson's disease; SRXRF, synchrotron radiation X-Ray fluorescence; AAS, atomic absorption spectroscopy; MT, metallothionein; PB, Prussian Blue; HE, hematoxilin and eosin 


\section{Abstract}

Aims of this investigation were to quantify copper $(\mathrm{Cu})$, iron ( $\mathrm{Fe})$ and zinc $(\mathrm{Zn})$ along with sulphur (S) and phosphorus $(P)$ in hepatocytes and connective tissue in liver section from patients with Wilson's disease (WD) by micro Synchrotron X-ray fluorescence ( $\mu$-SRXRF). Secondly to establish two-dimensional $\mu$-SRXRF element mappings for comparison with histologically prepared slices, and thirdly to assess whether elemental distributions are associated.

Methods: Archival liver tissues from twelve patients with end-stage cirrhosis or fulminant WD were investigated. Mutations in ATP7B have been classified before. For control seven archived normal liver tissues were investigated. $\mu$-SRXRF measurements were performed at the DORIS III storage ring at HASYLAB/DESY (Hamburg, Germany). Two-dimensional element distribution were compared with histologically prepared slices about $20-30 \mu \mathrm{m}$ apart from those investigated by $\mu$ SRXRF.

Results: Elementary copper $(\mathrm{Cu})$ could be demonstrated in all investigated liver sections simultaneously with $\mathrm{Fe}, \mathrm{Zn}, \mathrm{P}$ and $\mathrm{S}$. In WD mean Cu was 20 fold increased in hepatocytes and threefold in fibrotic areas in comparison with controls. In regeneration nodules $\mathrm{Cu}$ was strikingly inhomogeneous distributed. Cu concentrations measured by $\mu$-SRXRF correlated with those measured by atom absorption spectroscopy. Strong associations in their regional distribution existed between $\mathrm{Zn}$ and $\mathrm{Cu}$ or $\mathrm{Fe}$ and $\mathrm{S}$. Moreover, differences in $\mathrm{Cu} / \mathrm{S}$ were found between hepatocytes and fibrotic areas. An increase of Fe could only be documented in hepatocytes compared to fibrotic areas. With a beam size of $15 \times 15 \mu \mathrm{m}$ two-dimensional distributions of these elements are morphologically comparable with histological section with a magnification of about $25 x$ optic microscope.

Conclusions: $\mu$-SRXRF investigations are a valuable tool for quantifying element concentrations in biological tissues and further provide 2-dimensional information of element distribution and elemental association in a biological tissues, thus speeding up basic knowledge in a synopsis with biological and clinical data. 


\section{Introduction}

Wilson's disease (WD) is a disorder of impaired hepatic Cu transport due to mutations in ATP7B, which encodes the copper-transporting P-type ATPase, leading to copper accumulation in the liver and extrahepatic organs (1-4). The clinical diagnosis is often difficult and requires a combination of clinical, biochemical and genetic tests $(1,3)$. A fivefold increase of hepatic copper concentration $(\mathrm{Cu})$ measured by flame atomic absorption spectroscopy (AAS) is considered as diagnostic for Wilson disease (1). However AAS provides only a mean Cu concentration of the investigated biopsy. Due to sampling variation known regional differences in hepatic $\mathrm{Cu}$ distribution may be misleading from single biopsy specimen $(6,7)$. Less reliable is the histochemical demonstration of copper in liver tissue (6-8). Among histochemical stains for $\mathrm{Cu}$ Timm's silver stain seems to be the most sensitive method for the demonstration of copper while Rhodanine and Orcein have been proven to be less sensible in staining either free copper or copper-binding protein corresponding to metallothioneins, respectively (6-8). For quantitative imaging of metals in tissue electron microprobe (10), laser ablation coupled plasma mass spectroscopy - which is tissue destructive (11-12) and micro synchrotron-based X-ray fluorescence (micro-SRXRF) (15-19) have been introduced.

Metal and trace element investigations by micro Synchrotron X-ray fluorescence ( $\mu$ SRXRF) have increasingly expanded basic knowledge and clinical diagnosis (19) by determining element distribution in a variety of animal and human tissues (14-18). Since $\mu-S R X R F$ is a tissue sustaining physical method it is a valuable tool extending cooperatively and maximising biochemical and clinical research. Moreover, two or even three dimensional spatial distributions of metals and trace elements in tissues (19) are possible. Thus, and in this regard, determining multiple elements independently of their chemical state, archival (patho-) histological tissue are fascinating for investigations by $\mu-\operatorname{SRXRF}(20)$, together with clinical investigations. High sensibility and high resolution are maintained. In a recent paper a rapid and reliable diagnosis of Wilson disease using $X$-ray fluorescence is recommended, showing that relative $\mathrm{Cu}$ concentration related to iron and zinc can discriminate WD from other genetic or chronic liver diseases (21). Since only concentrations of light elements such as e.g. phosphorus (P) and sulphur (S) are slightly underestimated in paraffin embedded tissues (Osterode, Falkenberg personal communication and 22), 
$\mu$-SRXRF were used to investigate paraffin embedded tissues from WD patients to measure multiple elements independently of their chemical state $(20,23)$.

The aims of this study were to quantify copper $(\mathrm{Cu})$, iron $(\mathrm{Fe})$ and zinc $(\mathrm{Zn})$ concentrations along with sulphur $(S)$ and phosphorus $(P)$ in hepatocytes and connective tissue in liver from patients with WD; to establish two-dimensional $\mu$ SRXRF element mappings for comparing results with histologically prepared tissue, and finally to assess whether determined elements are associated with Cu distribution.

\section{Material and Methods}

\section{Tissue specimen and paraffin embedding}

Paraffin embedded liver tissue archived at the Klinisches Institut für Klinische Pathologie were used throughout our investigations. For paraffin embedding, tissue specimens where fixed in $4 \%$ buffered formalin for at least $24 \mathrm{~h}$, subsequently dehydrated in ethanol with increasing concentrations (70\% - 100\%). Ethanol clearing was done with Xylene, before soaking the tissue sample with molten paraffin wax for Xylene clearing. Finally, the waxed samples were embedded in paraffin blocks to be ready for further processing, such as cutting tissue slices by a microtome. These blocks were used for SRXRF investigations. Existing archival dyed slices (e.g. HE, PB or Rhodanine) from the same tissue block were used for comparison with our two dimensional $\mu$-SRXRF measurements. Standardized methods for dyeing which have been repeatedly described were applied $(7,8)$.

\section{Liver tissue}

\section{CONTROL}

For control, liver tissue from 7 patients (age: $50 \pm 6$ years) who died from cardiovascular failure or traffic accidents were investigated (CONTROL). Demographic and histological data of these specimen are given in Table 1a. 


\section{Patients with Wilson's disease}

Paraffin embedded liver tissue obtained from 12 WD patients were available. Ten patients underwent liver transplantation. Tissues blocks of about $3 \times 3 \times 2 \mathrm{~cm}^{3}$ existed. From two WD patients only needle biopsies (both $>2 \mathrm{~cm}$ in length) were found. In Tab.1b demographic data (at transplantation or at biopsy) along with mutations in ATP7B and Cu determined by AAS - before transplantation - are given.

\section{Tissue preparation for SRXRF investigations}

Paraffin embedded slices of $10 \mu \mathrm{m}$ of thickness were fixed on a trace element free Ultralene foil ${ }^{\circledR} 4 \mu \mathrm{m}$ of thickness for SRXRF investigation. These liver slices were about $30 \mu \mathrm{m}$ apart from those dyed for histological examinations.

\section{Microscopic synchrotron radiation X-ray fluorescence analysis}

The technical setup used for the performed measurements is extensively described in recent papers $(18,24)$. In short: microscopic synchrotron radiation X-ray fluorescence analysis ( $\mu$-SRXRF) measurements were performed at beamline $L$ at the DORIS III storage ring at HASYLAB/DESY in Hamburg. The beamline and standard experimental setup is given in Ref. (24). The white beam of the bending magnet was monochromatised at $17 \mathrm{keV}$ by a double multilayer monochromator ( $\mathrm{NiC}$ ). The monochromatic $\mathrm{X}$-ray beam was then focused by a polycapillary half-lens to a cross section of $15 \mu \mathrm{m}$ providing a flux of about $10^{11}$ photons/s $(25,26)$.

Liver slice samples were mounted on a XYZ-sample stage and scanned relative to the $X$-ray micro-beam at room temperature and in air environment. In the present study a constant sample time of $1.25 \mathrm{~s}$ per point was used. The increment in horizontal direction was $25 \mu \mathrm{m}$ and $15 \mu \mathrm{m}$ in vertical direction. Fluorescence photons and scattered radiation are detected by an energy-dispersive semiconductor detector.

\section{Quantification of elements}

For element quantification the x-ray spectra were peak-fitted using the AXIL program package (27), in order to extract the net intensities of fluorescence lines. The net peak intensities were normalized to the intensity of the incoming monochromatic beam intensity and $1 \mathrm{~s}$ sample time. A germanium standard foil of homogeneous $\mathrm{Ge}$ area density of $2.6 \times 10^{-7} \mathrm{~g} / \mathrm{cm}^{3}$ was employed for external standardization (24). Element 
concentrations were calculated from the normalized net peak intensities using the fundamental parameter method based program package "quant".

Sample thickness, measurement geometry and beam energy was unchanged during the measurement series. Therefore, the same set of element specific conversion factors could be applied for all measurements. In Fig. 1 sum spectra of complete 2D scans are exemplarily demonstrated for CONTROL and WD.

\section{Statistical analysis}

AXIL PC software for the analysis of complex X-ray spectra was used. Mean values for investigated elements within scanned areas were calculated. Results are reported as mean $\pm S D$. Differences between mean values were tested for significance by Student's t-test. Differences were considered to be significant if $p$-value was less than 0.05 (SigmaStat@ 3.5).

\section{Results}

\section{Reference Liver tissue}

Overall about 210,000 single measurements (i.e. analysed single spectra) in seven different reference liver sections (CONTROL) were analysed. Scans in CONTROL tissue are shown in Fig.2a-d. Only slight variations in element concentrations occur. Mean concentrations of investigated elements are shown in Tab.2. Data are in line with prior found values $(11-13,25)$. While $\mathrm{Cu} / \mathrm{S}$ and $\mathrm{Cu} / \mathrm{Zn}$ are clearly and positively associated, $\mathrm{Cu} / \mathrm{Fe}$ or Fe/Zn only seem to be weakly associated (Fig.4a-d). Values near zero presumably belong to vessel lumen areas larger than $15 \times 15 \mu^{2}$. Considering the huge number of single measurements some zero values do not significantly contribute to alterations in mean concentrations of elements. This is demonstrated in Fig.3. Even though e.g. a large vessel lumen is included (Fig.3) into the scan area, mean values for elements did not significantly change.

\section{Copper concentrations in WD tissue}

Overall more than 485,000 single measurements (i.e. analysed single spectra) in twelve patients with WD were analysed. Mean concentrations of investigated elements 
in WD and controls are given in Tab.2. In contrast to CONTROL elements in cirrhotic WD tissue are extremely uneven distributed. Highest $\mathrm{Cu}$ concentrations were found as expected - in WD hepatocytes with peak concentrations around 3500 ppm paraffinised liver tissue. Even in fibrotic tissue mean $\mathrm{Cu}$ was significantly increased in comparison with CONTROL. Hepatic $\mathrm{Zn}$ and iron concentrations in WD were not different from controls. However, in comparison with mean $\mathrm{Fe}$ in connective or fibrotic tissue, Fe in hepatocytes was significantly increased in WD (Table 2)

Cu concentrations determined by AAS from ten liver biopsies prior to transplantation were available. Values were compared with those $\mathrm{Cu}_{\mu \mathrm{SRXRF}}$ values in WD tissue that was taken and prepared after transplantation, and thus a tissue from a totally different liver area. A linear regression for CuAss and $\mathrm{Cu}_{\mu \mathrm{SRXRF}}$ resulted in that $\mathrm{Cu}_{\mathrm{AAS}}=1,96^{*}$ $\mathrm{Cu}_{\mu \mathrm{SRXRF}}-74,8\left(\mathrm{R}^{2}=0,79, \mathrm{p}<0,001\right)$ implying that $\mathrm{Cu}_{\mathrm{AAS}}>\mathrm{Cu}_{\mu \mathrm{SRXRF}}$ within our investigation (Fig. 5). In as far as $\mathrm{Cu}$ in native tissue (CuAss) and $\mathrm{Cu}_{\mu S R X R F}$ in parafinised tissue differ cannot be assessed at present.

\section{Two-dimensional investigations in WD tissue}

Fig.6 shows a two-dimensional distribution of $\mathrm{Cu}$ (Fig. 6c) compared with adjacent liver sections stained with haematoxilin-eosin (Fig. 6a) and Prussian Blue (PB staining is used to demonstrate $\mathrm{Fe}$ in histological slices, Fig.6b). Histology and $\mu$-SRXRF are directly matchable. It is evident that $\mathrm{Cu}$ is inhomogeneously distributed in cirrhotic nodules while Fe seems to be mainly peripherally disposed (Fig. 6d) indicating that $\mu$ SRXRF method outmatches histochemical methods. In contrast, $Z n$ did not show such striking differences in its distribution (Fig. 6e). In agreement with a previous study (18) the distribution compartment of bromine is the connective, fibrotic tissue (Fig. $6 f$ or Fig.2d).

In spite of the large standard deviation of mean tissue concentrations, a decrease in sulphur and phosphorous was documented in connective or fibrotic and nodular (mostly hepatocytes) tissues, respectively, compared with mean control values of $S$ and $P$. 


\section{Discussion}

Our paper demonstrates that $\mu-S R X R F$ is an exciting tool for investigating metals and trace elements in biological tissue. Even in paraffin embedded samples we were able to quantify concentrations of copper, iron, zinc, phosphorus and sulphur. Mean $\mathrm{Cu}$ concentration determined by AAS $(10,1)$, electron probe microanalyser with wavelength dispersive spectrometer (1) or other methods (10-13) correlated well with those measured by our $\mu$-SRXRF. In comparison with control tissue, overall mean $\mathrm{Cu}$ concentrations in WD were about tenfold increased, while in hepatocytes $\mathrm{Cu}$ was approximately 20 times higher. Heterogeneous distribution of $\mathrm{Cu}$ in WD liver tissue has been repeatedly reported. Striking differences were found even between adjacent macro areas of the same liver $(5,29)$. Extreme inhomogeneous $\mathrm{Cu}$ distribution within an area of $10-15 \mathrm{~mm}^{2}$ is shown in Fig.6c.

As recommended, a fivefold increase of hepatic copper concentration measured by flame atomic absorption spectroscopy (AAS) is considered as diagnostic for Wilson disease in combination with clinical, biochemical and genetic tests (1). Our results show that although mean concentrations of $\mathrm{Cu}, \mathrm{Fe}$ and $\mathrm{Zn}$ determined by $\mu$-SRXRF are in the range of earlier reported AAS values (29) determined in WD and in CONTROL tissue, they are not identical. However, since different tissues and tissue areas with inhomogeneous concentrations were investigated results seem plausible. Moreover, two-dimensional $\mathrm{Cu}$ concentrations with a huge \pm SD were compared with one single CuAss.Contributions of zero values to two-dimensional mean values seem to be negligible (Fig.3). Nevertheless, there was a significant linear correlation between hepatic $\mathrm{Cu}$ determined by AAS and that by $\mu$-SRXRF in quite different liver samples from same patients, each (Fig.5).

It is assumed that the frequent failure of histologically demonstrating $\mathrm{Cu}$ in WD tissue is caused by the fact that $\mathrm{Cu}$ atoms can only be detected in combination with stained proteins $(7,29)$. In contrast $\mu$-SRXRF detects $C u$ or other elements regardless of their ligands. Recently it was stated that the ratio of hepatic $\mathrm{Cu}$ to the sum of copper, iron and zinc measured by X-ray fluorescence (using only arbitrary units) discriminate WD from other genetic or chronic liver diseases (21). By quantifying elemental concentrations, this calculation of ratios is not necessary and scanning additionally 
tissue areas, two-dimensional elemental distribution can be investigated and can contribute to diagnosis.

With a focal beam size of $15 \mu \mathrm{m}$ in diameter quantitative element imaging resembles about a 25 times optic microscope resolution, so that comparisons with $\mathrm{HE}$ and/or other stained liver sections were directly feasible (Fig. 6a-d) especially since sections once prepared for histological diagnostic were only about 20-30 $\mu \mathrm{m}$ apart from those investigated by $\mu$-SRXRF.

Introducing scattergrams for element distributions in WD tissue, demonstrates on the one hand a new aspect for elucidating elemental associations in tissue and on the other hand a dichotomous distribution corresponding to fibrotic and hepatocyte areas (Fig.7c). This is of course different to normal liver tissue where no fibrosis exists (Fig.4 a-d).

Mean hepatic Fe and Zn in WD patients were statistically not different to controls. But, remarkably Fe showed unexpectedly great regional differences as seen e.g. in Fig. 6b (Prussian Blue staining) and Fig.6d ( $\mu$-SRXRF). Biochemically several metabolic links regarding intestinal uptake, hepatic storage and release between $\mathrm{Cu}, \mathrm{Fe}$ and $\mathrm{Zn}$ have been described (30-34).

Another interesting aspect is the strong association between $\mathrm{Cu} / \mathrm{Zn}$ and sulphur both in WD and in CONTROL (e.g. Fig.6b). Sulphur is an inherent part in metallothioneins (MT). MT binds copper in an atoxic form and both Zn and Cu can induce MT synthesis. But, by contrast, in our WD-patients both in fibrotic areas and hepatocytes mean sulphur concentration was significantly reduced compared to CONTROLs. This may indirectly indicate a reduction of MT. In WD-animal-models it could be shown however, that prolonged exposure to heavy metals causes MT release from the liver into the bloodstream where it is subsequently filtered through the glomerular kidney membrane. Thus, our data seem to support these experimental findings (35).

Study limitations may be seen in that archival paraffin embedded slices and not cryoslices have been used, a fact that may alter quantification results. Never the less, we recently could show that a clinical diagnosis could be achieved by using $\mu$-SRXRF even from archival paraffinised slices when biochemical or histochemical methods failed to detect heavy metals (14). Another limitation of our results is that mostly only small tissue specimen from only one area was available. The repeatedly described inhomogeneity in affected or cirrhotic liver parenchyma may lead to different results. And lastly, to validate our results for WD-specificity, comparisons with liver cirrhosis of 
different aetiology should be studied. At least for cirrhotic livers induced by hemochromatosis (genetically impaired Fe-metabolism) significant differences compared to WD livers exist (18).

In conclusion, quantitative $\mu$-SRXRF provides an insight in element distribution even in archival histological slices. Additionally two-dimensional distributions of elements are matchable with morphological features and can reveal elemental associations in different tissues speeding up basic knowledge in a synopsis with biological and clinical data.

\section{Conflicts of Interest}

The authors declare no financial, consulting, or personal conflicts of interest. P.F.: Advisor to Wilson Therapeutics, Univar and Vivet Therapeutics 


\section{References}

1. European Association for the Study of the liver. EASL. Clinical Practice Guidelines: Wilson's disease. J Hepatol 2012; 56: 671-685.

2. Ferenci P. Wilson's Disease. Clin Gastroenterol Hepatol 2005; 3(8): 726-33.

3. Ferenci P, Steindl-Munda P, Vogel W, Jessner W, Gschwantler M, Stauber R, Datz C, Hackl $F$, Wrba $F$, Bauer $P$, Lorenz $O$. Diagnostic value of quantitative hepatic copper determination in patients with Wilson's Disease. Clin Gastroenterol Hepatol. 2005; 3(8):811-8.

4. Gitlin JD. Wilson disease.Gastroenterology 2003;125(6):1868-77.

5. Faa G, Nurchi V, Demelia L, Ambu R, Parodo G, Congiu T, Sciot R, Van Eyken P, Silvagni R, Crisponi G. Uneven hepatic copper distribution in Wilson's disease. J Hepatol 1995; 22(3): 303-8.

6. McDonald JA, Snitch P, Painter D, Hensley W, Gallagher ND, McCaughan GW. Striking variability of hepatic copper levels in fulminant hepatic failure. J Gastroenterol Hepatol 1992; 7(4): 396-398.

7. Pilloni L, Lecca S, Van Eyken P, Flore C, Demelia L, Pilleri G, Nurchi AM, Farci AM, Ambu R, Callea F, Faa G. Value of histochemical stains for copper in the diagnosis of Wilson's disease. Histopathology 1998; 33(1): 28-33.

8. Lecca S, Pilloni L, Ambu R, Flore C, Callea F, Faa G. Multiple histochemical methods in the diagnosis of Wilson's disease. Presentation of 74 cases and review of the literature, Pathologica 1998; 90(6): 771-775.

9. Fuentealba I.C, Haywood S, Trafford J, Evaluation of histochemical methods for the detection of copper overload in rat liver. Liver 1987; 7(5): 277-282.

10. Watanabe K, Miyakawa $\mathrm{O}$, Kobayashi $\mathrm{M}$. New method for quantitative mapping of metallic elements in tissue sections by electron probe microanalyser with wavelength dispersive spectrometers, J. Electron. Microsc. (Tokyo) 2001; 50(1): 77-82.

11. Todd PJ, Schaaff TG, Chaurand P, Caprioli RM. Organic ion imaging of biological tissue with secondary ion mass spectrometry and matrix-assisted laser desorption/ionization. J Mass Spectrom 2001; 36(4): 355-369.

12. Şahin M, Fahri K, Erdogan KE, Bas T, Colak T. Liver tissue trace element levels in HepB patients and the relationship of these elements with histological injury in the liver and with clinical parameters. J Trace Elem Med Biol 2018; 45: 70-77.

13. Kindness A, Sekaran CN, Feldmann J. Two-dimensional mapping of copper and zinc in liver sections by laser ablation-inductively coupled plasma mass spectrometry. Clin Chem 2003; 49(11): 1916-1923.

14. Breier F, Loader D, Wasilewicz G, Brenner W, Sator P, Feldmann R, Stella A, Osterode W, Falkenberg G, Steiner A, Jurecka W. Intradermal metal deposits in an industrial worker [Intradermale Metalleinsprengungen bei einem Industriearbeiter]. Hautarzt 2016; 67 (1): 64-68.

15. Milman N, Laursen J, Podenphant J, Staun-Olsen P. Iron, copper, zinc and selenium in human liver tissue measured by X-ray fluorescence spectrometry, Scand I Clin Lab Invest 1983; 43(8): 691-697.

16. Milman N, Laursen J, Podenphant J, Asnaes S. Trace elements in normal and cirrhotic human liver tissue, I. Iron, copper, zinc, selenium, manganese, titanium and lead measured by X-ray fluorescence spectrometry. Liver 1986; 6(2):111-117.

17. Zoeger N, Streli C, Wobrauschek P, Jokubonis C, Pepponi G, Roschger P, Bohic S, Osterode W. Powder Diffraction. Elemental mapping in slices of human brain by SR- $\mu$ XRF. Powder Diffraction 2005; 20 (2): 158-160.

18. Osterode W, Falkenberg G, Höftberger R, Wrba F. Iron, copper, zinc and bromine mapping in cirrhotic liver slices from patients with hemochromatosis studied by $\mu$-SRXRF 
in continuous scanning mode. Spectrochim Acta Part B Atomic Spectroscopy 2007; 62: 682-688.

19. Zoeger N, Roschger P, Hofstaetter JG, Jokubonis C, Pepponi G, Falkenberg G, Fratzl P,Berzlanovich A, Osterode W, Streli C,Wobrauschek, P. Lead accumulation in tidemark of articular cartilage. Osteoarthritis and Cartilage 2006; 14 (9): 906-913.

20. McRae R, Bagchi P, Sumalekshmy S, Fahrni CJ. In situ imaging of metals in cells and tissues. Chemical Reviews 2009; 109(10): 4780-4827.

21. Kaščáková S, Kewish CM, Rouzière $S$, Schmitt F, Sobesky R, Poupon J, Sandt C, Francou B, Somogyi A, Samuel D, Jacquemin E, Dubart-Kupperschmitt A, Nguyen TH, Bazin D, Duclos-Vallée JC, Guettier C, Le Naour F. Rapid and reliable diagnosis of Wilson disease using X-ray fluorescence. J Pathol Clin Res. 2016 Jun 6;2(3):175-86. doi: 10.1002/cjp2.48. eCollection 2016 Jul.

22. Chwiej, J., Szczerbowska-Boruchowska, M., Lankosz, M., Wojcik, S., Falkenberg, G., Stegowski, Z.,Setkowicz, Z. Preparation of tissue samples for X-ray fluorescence microscopy Spectrochimica Acta-Part B Atomic Spectroscopy 2005, 60 (12): 1531-1537.

23. Ralle M, Lutsenko S. Quantitative imaging of metals in tissues. BioMetals 2009; 22 (1): 197-205.

24. Falkenberg G, Osterode W. Räumliche Abbildung der Verteilung von Spurenelementen auf mikorskopischem Niveau: Wo sitzt das Blei in menschlichen Knochen? Mikroskopische Röntgenfluoreszenzanalyse. In Forschung mit Synchrotronstrahlung. Eine Einführung in die Grundlagen und Anwendungen. Eds. Falta J and Möller T. 2010 Vieweg+Teubner

25. Falkenberg G, Tschentscher Th, Clauss O. X-ray optics for the microfocus beamline L, In Hasylab Annual Report 2001; www-hasylab.desy.de/science/annual_reports /2001_report/part1/intern/5720.pdf.

26. Proost K, Vincze L, Janssens K, Gao N, Bulska E, Schreiner M, Falkenberg G. Characterization of a polycapillary lens for use in micro-XANES experiments. X-ray Spectrometry 2003, 32(3): 215-222.

27. Kühbacher M, Weseloh G, Thomzig A, Kneipp J, Beekes M, Falkenberg G, Radtke $M$, Riesemeier H, Kyriakopoulos A, Behne D. Analysis and Location of Metal- and MetalloidContaining Proteins by Synchrotron Radiation X-Ray Fluorescence Spectrometry, X-Ray Spectrometry 2005; 34:112-117.

28. Feuerborn J, Knöchel A, Meyer AK, Lechtenberg F, Falkenberg G, Rickers K. Sputtered Germanium Films as an Internal Standard for Quantitative X-Ray Fluorescence Analysis of Thin Film Samples, In Hasylab Annual Report 2002, www.hasylab.desy.de/science/annual_reports/2002_report/part1/contrib/47/7296.pdf.

29. Goldfischer S, Popper $H$, Sternlieb I. The significance of variation in the distribution of copper in disease. Am J Pathol 1980; 99: 715-730.

30. Garrick MD, Nunez MT, Olivares M, Harris ED. Parallels and contrasts between iron and copper metabolism. Biometals 2003; 16(1): 1-8.

31. Fox PL. The copper-iron chronicles: The story of an intimate relationship. Bio Metals 2003; 16: 9-40.

32. Arredondo Arredondo M, Cambiazo V, Tapia L, Gonzalez-Aguero M, Nunez MT, Uauy R, Gonzalez M. Copper overload affects copper and iron metabolism in Hep-G2 cells. Am J Physiol Gastrointest Liver Physiol 2004; 287(1): G27-32.

33. Attieh, ZK, Mukhopadhyay CK, Seshadrit V, Tripoulas NA, Fox P. Ceruloplasmin Ferroxidase Activity Stimulates Cellular Iron Uptake by a Trivalent Cation-specific Transport Mechanism. J Biol Chem 1999; 274: 1116-1123.

34. Chen H, Attieh ZK, Dang T, Huang G, Van Der Hee RM, Vulpe C. Decreased hephaestin expression and activity leads to decreased iron efflux from differentiated $\mathrm{CacO} 2$ cells. J Cellular Biochemistry 2009; 107 (4): 803-808. 
35. Santon A, Giannetto S, Sturniolo G, Medici V, D'Incà R, Irato P, Albergoni V. Interactions between $\mathrm{Zn}$ and $\mathrm{Cu}$ in LEC rats, an animal model of Wilson's disease. Histochemistry and Cell Biology 2002; 117 (3):275-281. 


\section{Tables}

Table 1a.

\section{Demographic and histological data of Controls}

\begin{tabular}{|c|c|c|c|c|c|c|c|}
\hline \multirow[t]{2}{*}{ Control } & \multirow[t]{2}{*}{ age [y] } & \multirow[t]{2}{*}{ gender } & \multirow[t]{2}{*}{ Tissue } & \multicolumn{4}{|c|}{ Histology } \\
\hline & & & & LBS & FDG & $\mathrm{SC}$ & SoI \\
\hline 1 & 45 & $\mathrm{~m}$ & Block & pre & no & $( \pm)$ & no \\
\hline 2 & 44 & $\mathrm{f}$ & Block & pre & no & no & no \\
\hline 3 & 32 & $\mathrm{~m}$ & NB & pre & no & no & no \\
\hline 4 & 62 & $\mathrm{~m}$ & NB & pre & $( \pm)$ & no & no \\
\hline 5 & 58 & $\mathrm{f}$ & Block & pre & no & no & no \\
\hline 6 & 48 & $\mathrm{~m}$ & Block & pre & no & no & no \\
\hline 7 & 61 & $\mathrm{~m}$ & Block & pre & $( \pm)$ & $( \pm)$ & no \\
\hline
\end{tabular}

Table1a. Demographic data of Control liver tissue mostly used as donor liver for liver transplantation. Age [y] at the time of liver explantation (small Block tissue) or Needle Biopsy (NB). Ratings for preserved liver structure (lobular structure (LBS)), lobular structure preserved (pre), signs of fatty degeneration (FDG), signs of cholestasis (SC) and signs of inflammations (Sol) were done by two pathologists. 
Table $1 b$.

\section{Demographic data of WD patients}

\begin{tabular}{|c|c|c|c|c|c|c|c|c|}
\hline Patient No & $\begin{array}{r}\text { age } \\
{[y]}\end{array}$ & gender & $\begin{array}{l}\text { Clinical } \\
\text { presentation }\end{array}$ & $\begin{array}{l}\mathrm{Cu}_{\mathrm{AAS}} \\
{[\mu \mathrm{g} / \mathrm{g}} \\
\text { dry weight] }\end{array}$ & $\begin{array}{l}\mathrm{CPL} \\
{[\mathrm{mg} / \mathrm{dl}]}\end{array}$ & Rho & PB & $\begin{array}{l}\text { Mutations* } \\
\text { in ATPB7 }\end{array}$ \\
\hline 1 & 29 & $\mathrm{f}$ & decomp. Cirrh. & 1115 & 9 & - & - & $\mathrm{H} 1069 \mathrm{Q} / ?$ \\
\hline 2 & 16 & $\mathrm{f}$ & decomp. Cirrh. & NA & 8.5 & - & + & $? / ?$ \\
\hline 3 & 40 & $\mathrm{~m}$ & decomp. Cirrh. & 645 & 6 & + & + & $\mathrm{R} 1319 \mathrm{X} / ?$ \\
\hline 4 & 18 & $\mathrm{f}$ & fulminant WD & 318 & 39 & + & - & H1069Q/G1061R \\
\hline 5 & 32 & $\mathrm{~m}$ & decomp. Cirrh. & 2060 & 21.7 & + & - & G710A/G710A \\
\hline 6 & 11 & $\mathrm{f}$ & fulminant WD & 1278 & 18.7 & - & + & H1069Q/R816S \\
\hline 7 & 48 & $\mathrm{~m}$ & decomp. Cirrh. & 264 & 10 & + & + & $\mathrm{H} 1069 \mathrm{Q} / ?$ \\
\hline 8 & 26 & $\mathrm{f}$ & decomp. Cirrh. & 1128 & 9 & + & - & H1069Q/K832R \\
\hline 9 & 29 & $\mathrm{f}$ & fulminant WD & 625 & 26 & - & + & $? / ?$ \\
\hline 10 & 25 & $\mathrm{f}$ & fulminant WD & NA & NA & + & + & H1069Q/H1069Q \\
\hline 11 & 10 & $\mathrm{f}$ & abnormal LFT & 796 & 20 & $(+)$ & - & H1069Q/L1305P \\
\hline 12 & 21 & $\mathrm{f}$ & fulminant WD & 590 & 9 & - & + & I1148T/? \\
\hline
\end{tabular}

Table1b. Demographic data of the WD patients. Age [y] and gender with documented Wilson's disease. Additionally, results are given for Cu-dyeing with Rhodanine (Rho) and Fe-dyeing with Prussian Blue (PB) $(+$ : $\mathrm{Cu} / \mathrm{Fe}$ positive by histological ratings), CPL: Ceruloplasmin is the major copper-carrying protein in the blood, and plays additionally a role in iron metabolism; Reference: 20-60 [mg/dl]), copper concentration in liver determined by AAS CuAAS, and mutations (?: mutation not detected). *Mutation analysis for ATPB7 was carried out for exons 2 to 21 . $\mathrm{NA}=$ not available 


\section{Table 2}

\section{Mean concentrations of determined elements in Controls and WD}

\begin{tabular}{|c|c|c|c|c|c|c|}
\hline & & $\begin{array}{l}\mathbf{P} \\
{[\mathrm{ppm}]}\end{array}$ & $\begin{array}{l}\mathbf{S} \\
{[\mathrm{ppm}]}\end{array}$ & $\begin{array}{l}\mathbf{C u} \\
{[\mathrm{ppm}]}\end{array}$ & $\begin{array}{l}\mathbf{F e} \\
{[\mathrm{ppm}]}\end{array}$ & $\begin{array}{l}\mathbf{Z n} \\
{[\mathrm{ppm}]}\end{array}$ \\
\hline \multirow[t]{2}{*}{ CONTROL } & $N=7$ & & & & & \\
\hline & $\begin{array}{l}\text { mean } \\
\text { SD }\end{array}$ & $\begin{array}{r}1866 \\
503\end{array}$ & $\begin{array}{r}2681 \\
426\end{array}$ & $\begin{array}{r}19 \\
5\end{array}$ & $\begin{array}{r}309 \\
87\end{array}$ & $\begin{array}{l}68 \\
21\end{array}$ \\
\hline WD & $\mathrm{N}=12$ & & & & & \\
\hline Total & $\begin{array}{l}\text { mean } \\
\text { SD }\end{array}$ & $\begin{array}{r}1342 \\
715\end{array}$ & $\begin{array}{c}1749^{\mathrm{a}} \\
684\end{array}$ & $\begin{array}{l}241^{\mathrm{a}} \\
149\end{array}$ & $\begin{array}{r}272 \\
79\end{array}$ & $\begin{array}{l}57 \\
20\end{array}$ \\
\hline FA & $\begin{array}{l}\text { mean } \\
\text { SD }\end{array}$ & $\begin{array}{c}1267^{\mathrm{a}} \\
456\end{array}$ & $\begin{array}{c}1718^{\mathrm{a}} \\
295\end{array}$ & $\begin{array}{l}83^{\mathrm{a}} \\
14\end{array}$ & $\begin{array}{r}238 \\
99\end{array}$ & $\begin{array}{l}55 \\
12\end{array}$ \\
\hline Hepatocytes & $\begin{array}{l}\text { mean } \\
\text { SD }\end{array}$ & $\begin{array}{c}1321^{\mathrm{a}} \\
478\end{array}$ & $\begin{array}{l}2081^{\mathrm{a}} \\
380\end{array}$ & $\begin{array}{c}456^{\mathrm{a}, \mathrm{b}} \\
110\end{array}$ & $\begin{array}{l}367^{\mathrm{b}} \\
148\end{array}$ & $\begin{array}{l}69 \\
12\end{array}$ \\
\hline
\end{tabular}

Tab. 2. Mean values $( \pm S D)$ for elements in normal liver tissue (CONTROL) and for WD liver tissue given in ppm ( $\mu \mathrm{g} / \mathrm{g}$ sample weight) determined by micro-SRXRF. a: significant differences in comparison with control. b: significant differences between not nodular, fibrotic areas (FA) and nodular tissue (hepatocytes). 


\section{Figures}

Figure 1

Comparison between accumulated spectra in

Controls and WD

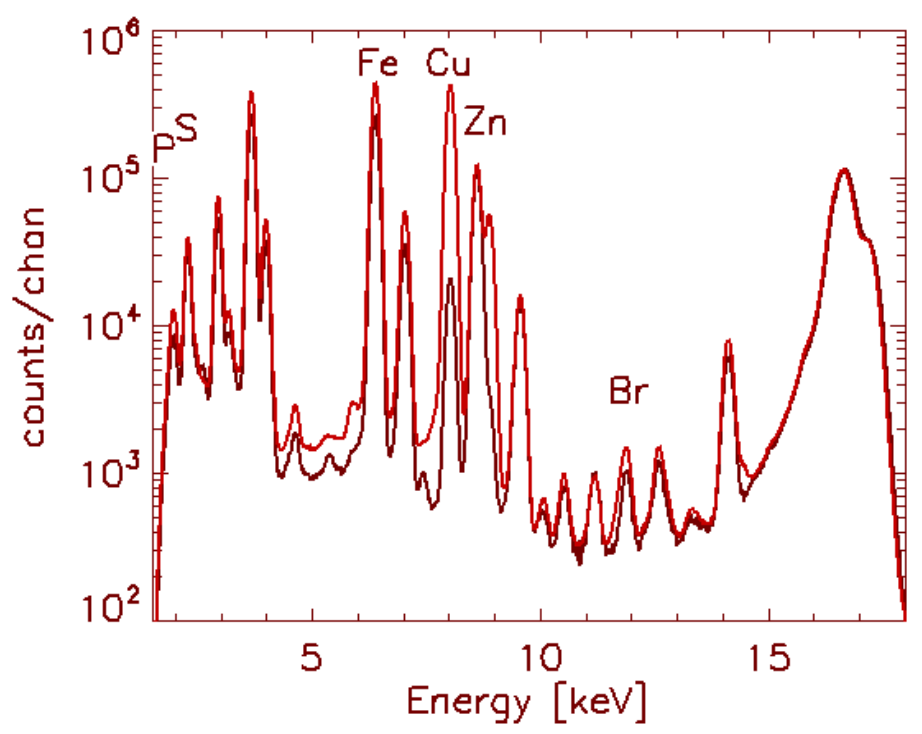

Fig.1.Accumulated spectra after summation over all pixels of reference liver tissue (black), and liver from a WD patient (red). Detected elements are P, S, Fe, Cu, Zn and Br (Bromine). 
Fig. 2

\section{Elemental Distribution in CONTROL liver tissue}
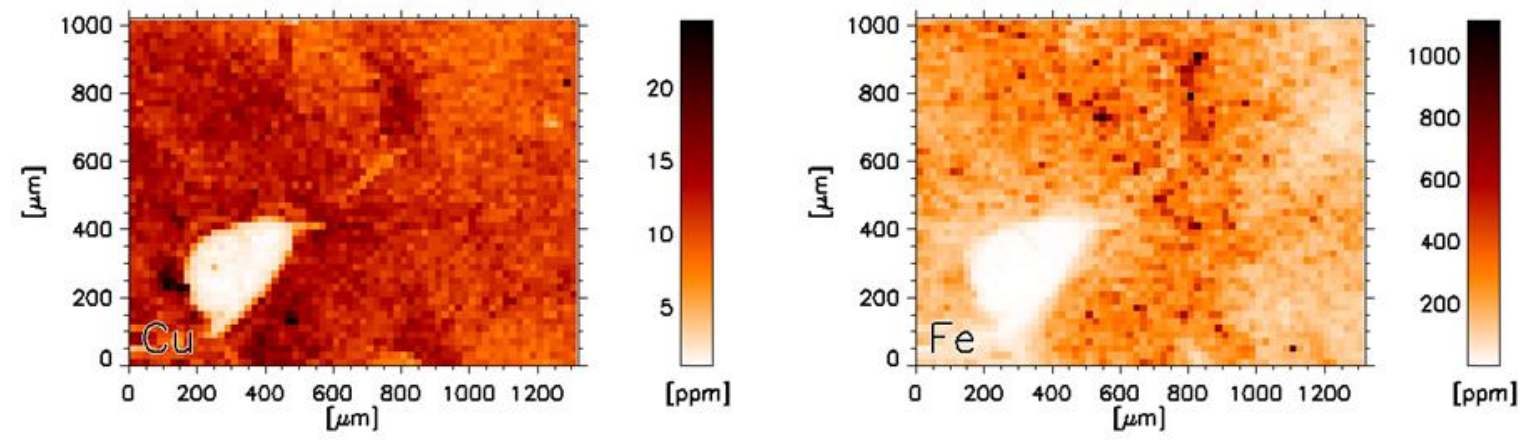

Fig. 2a

Fig. 2b
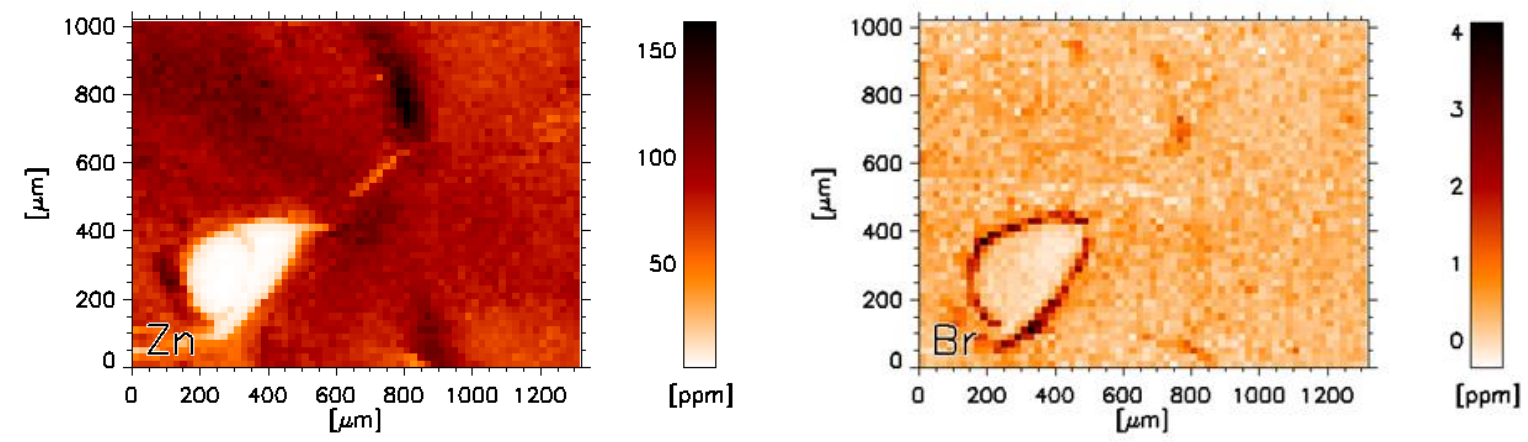

Fig. 2c

Fig.2d

Fig. 2a-d. Two-dimensional distribution in CONTROL liver tissue (Table 1a, Nr.1) showing only small variations in their concentrations given in ppm. The vessel lumen (left) is presumably a bile duct. 
Figure 3

\section{Comparisons between mean intensities of different}

liver tissue areas and whole scan

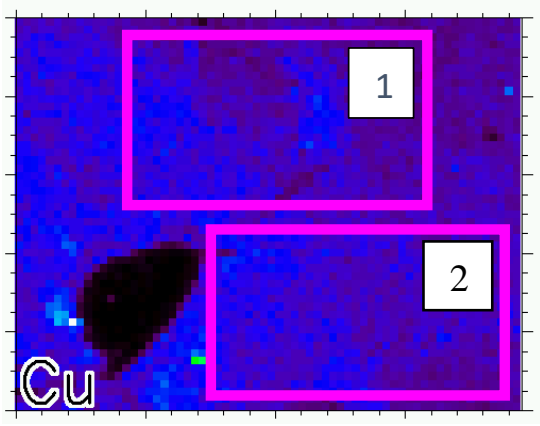

200

150

100

50

Counts/sec

Fig. 3. Original colour coded $\mu$-SRXRF scan for $\mathrm{Cu}$ (counts/sec) and correspond to Fig.2a. Relative element concentrations are compared with Area 1, Area 2 and whole area of the scan, an area with zero counts.

\section{Area 1:}

\begin{tabular}{lll} 
[counts/sec] & Mean & \pm SD \\
\hline $\mathrm{Cu}$ & 32.5 & 6.2 \\
$\mathrm{Fe}$ & 118.6 & 57.2 \\
$\mathrm{Zn}$ & 172.5 & 32.2
\end{tabular}

Area 2:

$\begin{array}{lll}\text { [counts/sec] } & \text { Mean } & \pm S D \\ \mathrm{Cu} & 34.0 & 8.2 \\ \mathrm{Fe} & 105.2 & 58.6 \\ \mathrm{Zn} & 171.2 & 39.9\end{array}$

Whole Scan:

$\begin{array}{lll}\text { [counts/sec] } & \text { Mean } & \pm S D \\ \mathrm{Cu} & 34.7 & 10.77 \\ \mathrm{Fe} & 106.3 & 56.3 \\ \mathrm{Zn} & 165.6 & 48.9\end{array}$




\section{Figure 4}

Scattergrams for metal associations in CONTROL liver tissue
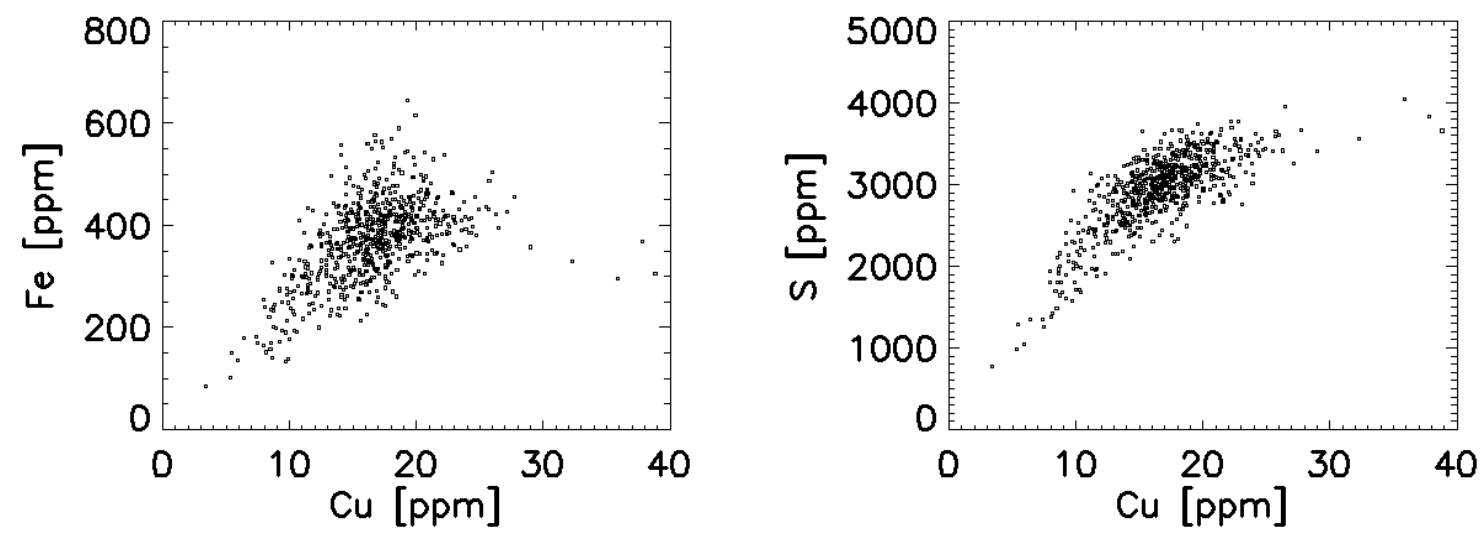

Fig. $4 \mathrm{a}$

Fig. 4b

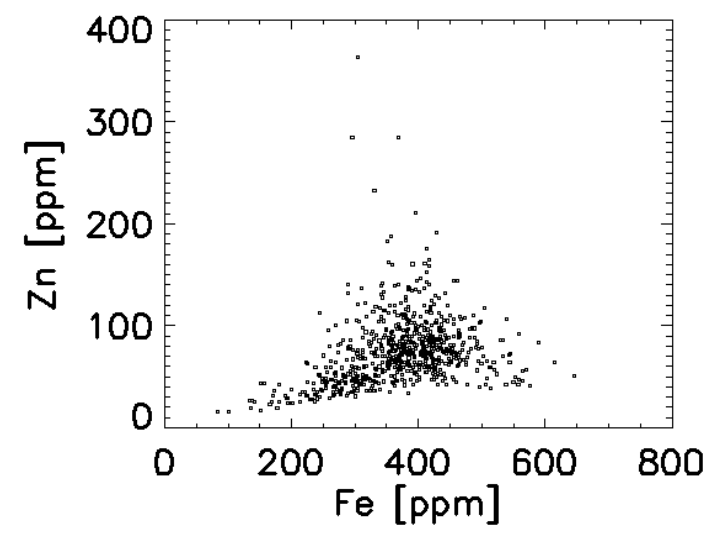

Fig.4c

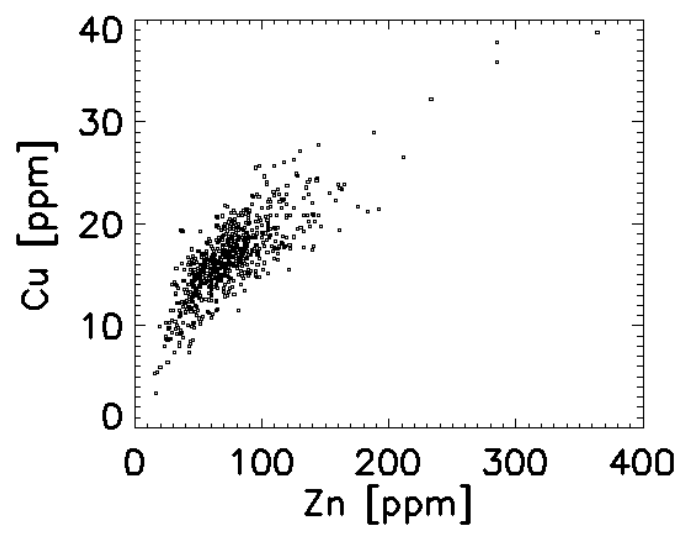

Fig. 4d

Fig. 4. Scattergrams showing potential associations between copper ( $\mathrm{Cu}$ ), iron $(\mathrm{Fe})$ zinc $(\mathrm{Zn})$, and Sulphur (S), respectively in a reference liver tissue (Table 1a, Nr.1 and corresponding to Area 1 in Fig.3a. 
Figure 5

\section{Correlation between $\mathrm{Cu}$ AAs and $\mathrm{Cu} \mu-\mathrm{SRXRF}$}

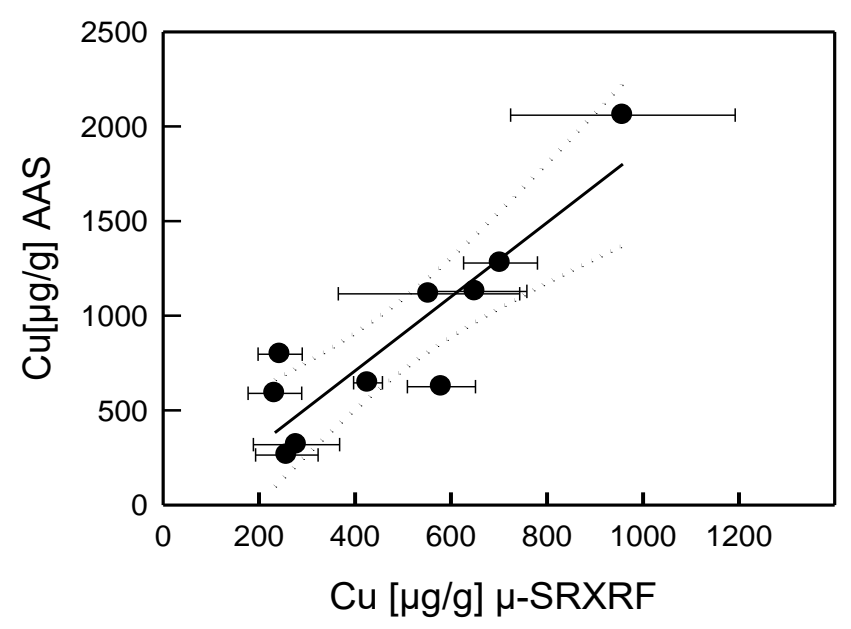

Fig. 5. Correlation between mean copper concentration $(\mathrm{Cu})$ determined by microscopic synchrotron radiation $\mathrm{X}$ ray fluorescence analysis ( $\mu$-SRXRF) and ten available $\mathrm{Cu}$ concentrations (needle biopsies) determined by atomic absorptions spectrometry (AAS). $\mathrm{Cu}_{\mathrm{AAS}}=1,96 * \mathrm{Cu}_{\mu \text {-SRXRF }}-74,8\left(\mathrm{r}^{2}=0,79, \mathrm{p}<0,001\right)$; dotted curved lines $95 \%$ confidence intervals. 


\section{Figure 6}

Comparisons between histologically prepared WD tissue and 2-

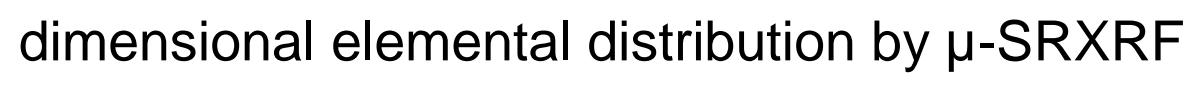

$\mathrm{HE}$

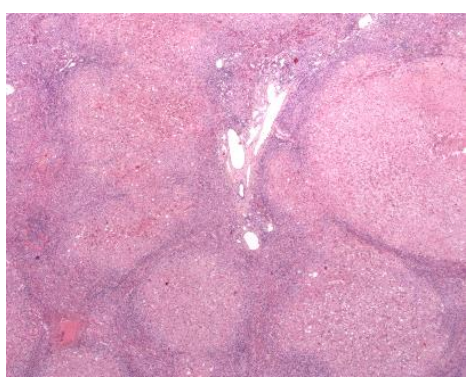

Fig. $6 \mathrm{a}$

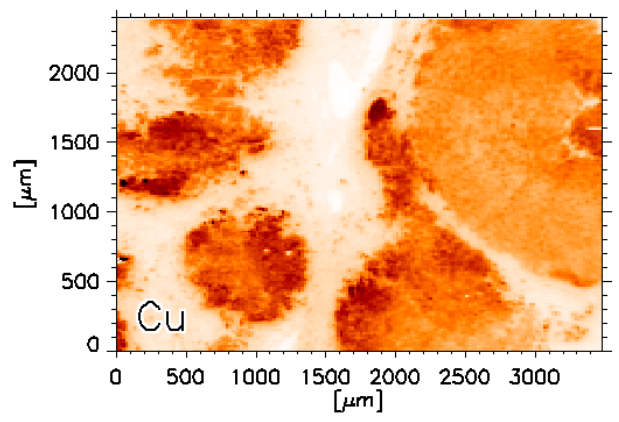

Fig. 6c

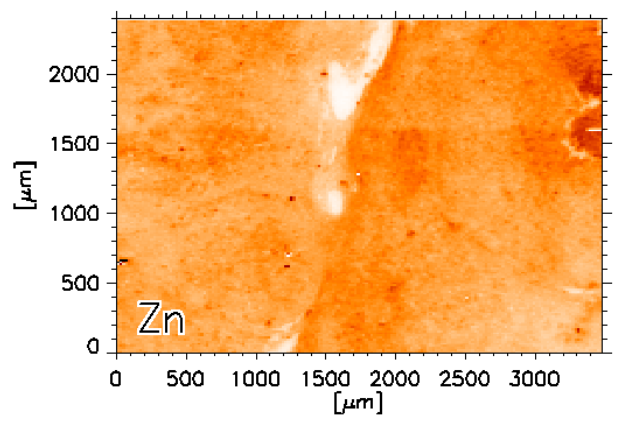

Fig. 6e
PB

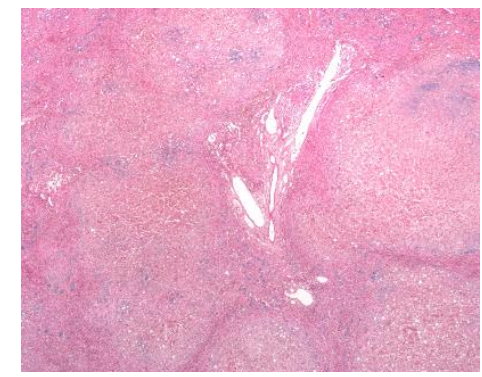

Fig.6b
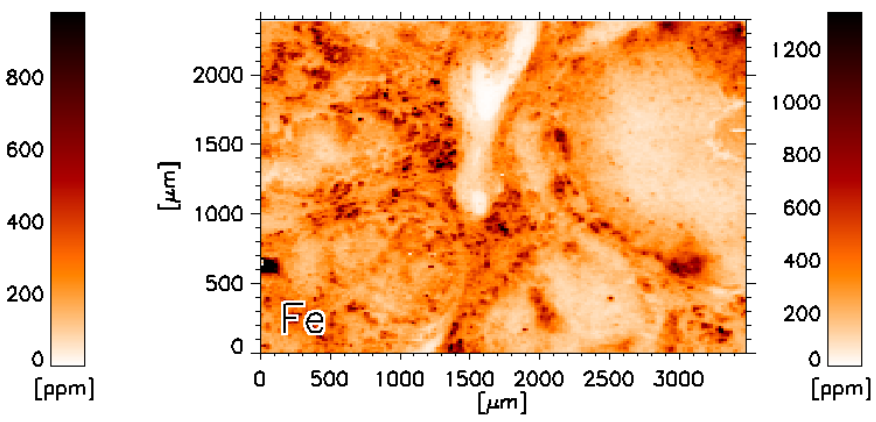

Fig.6d
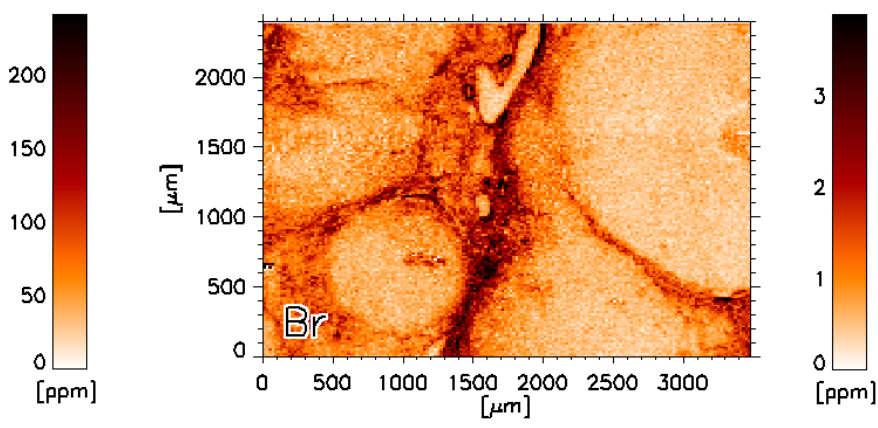

Fig. $6 f$

Fig.6. $2 \mathrm{D}$ distribution of $\mathrm{Cu}, \mathrm{Fe}, \mathrm{Zn}$ and Bromine $(\mathrm{Br})$ in a liver section of a WD patient in comparison with histochemical slices (Fig.4a: HE (hematoxilin/eosin dyeing), Fig.4b Fe detection by Prussian Blue dyeing (25x optic microscope). 


\section{Figure 7}

\section{Element distribution in hepatocytes and fibrotic areas}

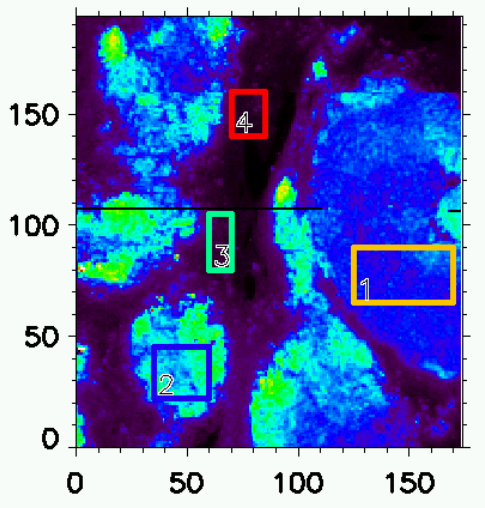

Fig.7a

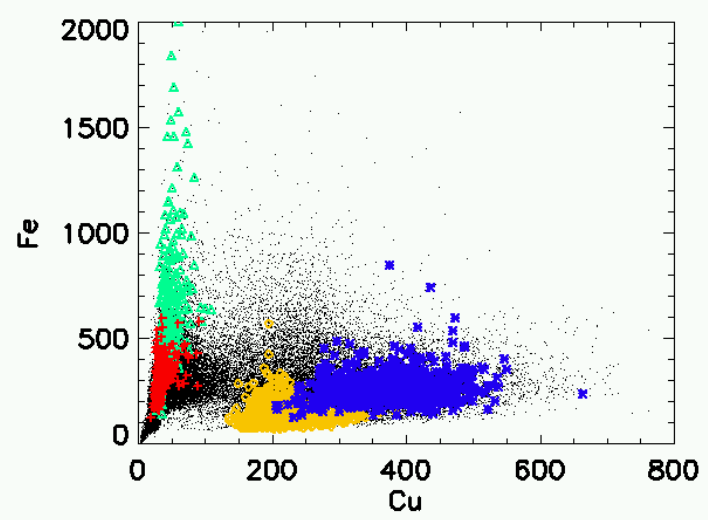

Fig.7c

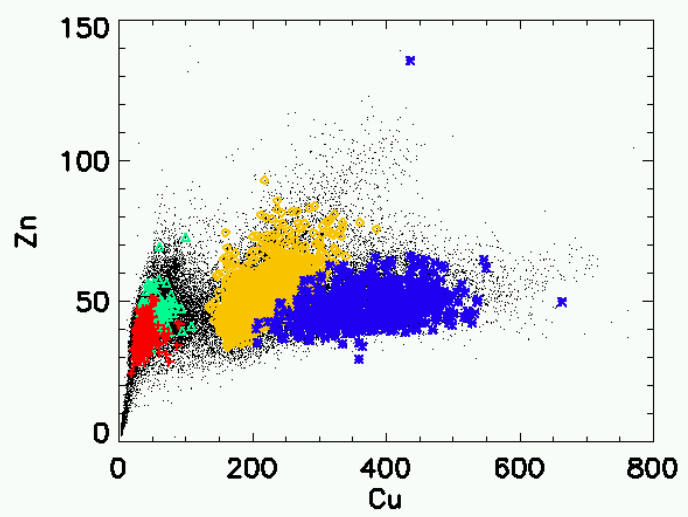

Fig.7e

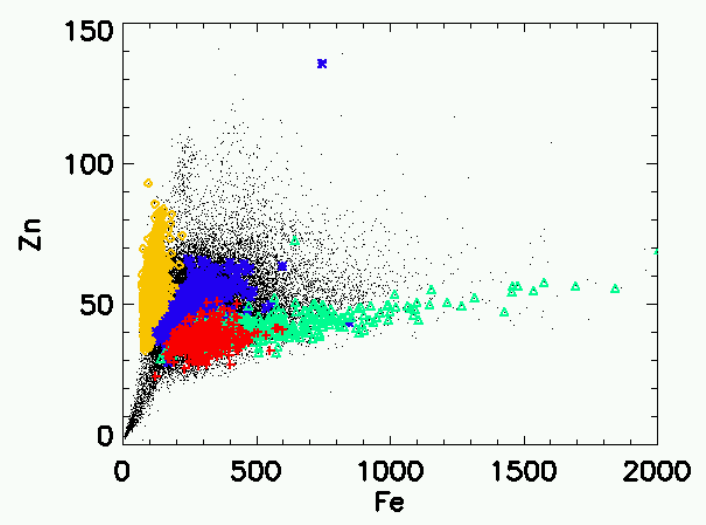

Fig. $7 b$

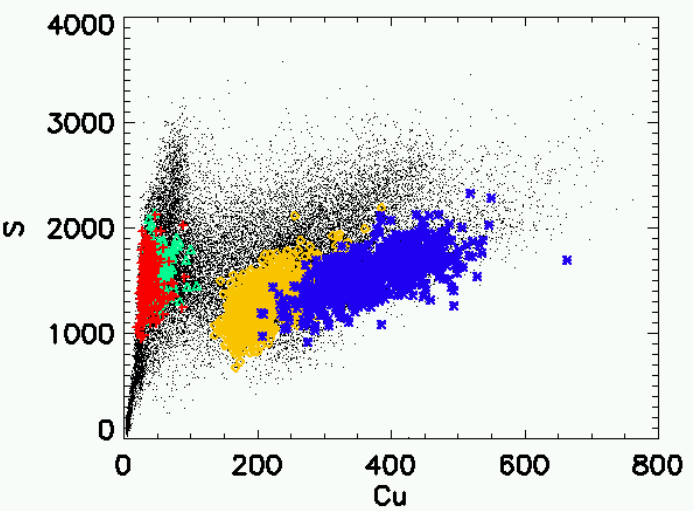

Fig.7d

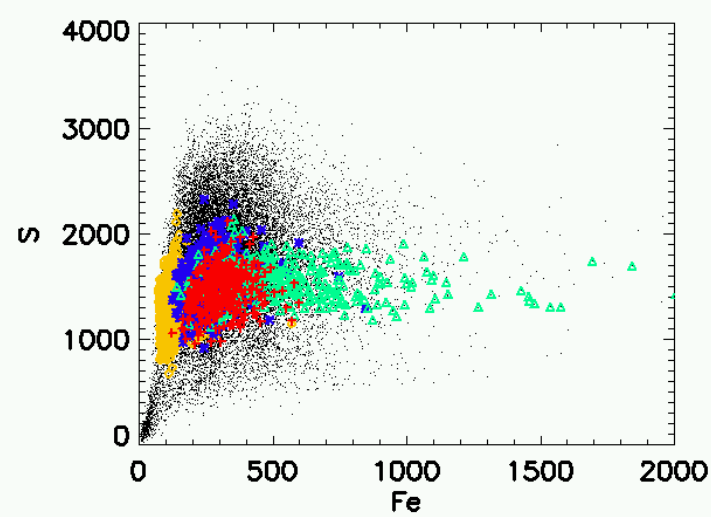

Fig.7f

Fig. 7a-f. Scattergrams of elements in WD tissue comprising all determined element concentrations (filled black points) from the 2D scan as shown in Fig. 4c or 5a (case No 1 in Table1). Regions of interest (ROI) are given in Fig 5a. ROI 1 and ROI 2 (blue and orange coloured ROI and points): hepatocytes; ROI 3 or 4 (red and green coloured ROI and points) refer to fibrotic areas. Concentrations for $\mathrm{Cu}, \mathrm{Fe}, \mathrm{Z}$, and $\mathrm{S}$ are given in $\mu \mathrm{g} / \mathrm{g}$ paraffinised tissue. 